\title{
Methane dynamics in a shallow non-tidal estuary (Randers Fjord, Denmark)
}

\author{
Gwenaël Abril*, Niels Iversen** \\ Aalborg University, Department of Life Science, Environmental Engineering Laboratory, Sohngaardsholmsvej 57, \\ 9000 Aalborg, Denmark
}

\begin{abstract}
Methane concentrations, oxidation rates, exchanges at the sediment-water interface and emissions to the atmosphere were studied between February and December 2000 along an estuarine gradient in Randers Fjord (Denmark). Methane concentrations measured at 3 stations, 1 in freshwater, 1 in brackish water (salinity 3 to 7 ) and 1 in saltwater (salinity 17 to 23), showed high supersaturation with respect to atmospheric equilibrium, with concentrations ranging from 186-420, 70-290 and 28-124 nM and median concentrations of 347, 125 and $41 \mathrm{nM}$ respectively. Calculated median fluxes to the atmosphere were 355, 126 and $40 \mu \mathrm{mol} \mathrm{m} \mathrm{m}^{-1}$ at the 3 stations respectively. The contribution of water-column methane oxidation to the total methane sinks (oxidation and emission) was 22 to $42 \%$ in the river (depth $8 \mathrm{~m}$ ), but fell to less than $3 \%$ at the brackish station, owing to lower rates and shallow depth $(1.7 \mathrm{~m})$. No oxidation could be detected in the saltwater. Methane fluxes through the sediment-water interface were directed downwards at the brackish station (from -19 to $-353 \mu \mathrm{mol} \mathrm{m} \mathrm{m}^{-2} \mathrm{~d}^{-1}$ in December and July respectively) and upwards at the saltwater station (from 3 to $400 \mu \mathrm{mol} \mathrm{m}{ }^{-2} \mathrm{~d}^{-1}$ in March and July respectively). At the brackish station, methane uptake by the sediment accounted for 16 to $55 \%$ of the total methane sink. Potential aerobic methane oxidation in surface sediments revealed the presence of a population of methanotrophs active at ambient methane concentrations at the brackish station, but not at the saltwater station. During summer, methane production at the saltwater station appeared to occur in the first $1 \mathrm{~cm}$ of the sediment and was 40 times higher than at the brackish station. The turnover time of methane relative to all sinks was 4 to $7 \mathrm{~d}$ in the freshwater, 0.5 to $1.8 \mathrm{~d}$ in the brackish water and 0.6 to $4.7 \mathrm{~d}$ in the saltwater. Our results confirm the important role of the estuarine zone in recycling methane. Most of the methane carried by the river is oxidised and released to the atmosphere in the upper estuary, and new production of methane occurs in the lower estuary, where, in addition, oxidation is inefficient.
\end{abstract}

KEY WORDS: Riverine methane - Estuary · Sediment · Aerobic methane oxidation · Methane production

Resale or republication not permitted without written consent of the publisher

\section{INTRODUCTION}

Methane is an atmospheric trace gas that contributes significantly to the greenhouse effect. The methane concentration in the atmosphere has been increasing over the last century, indicating that sources are larger

\footnotetext{
*Present address: Université Bordeaux 1, Département de Géologie et Océanographie, CNRS-UMR EPOC 5805, Avenue des Facultés, 33405 Talence, France

${ }^{* *}$ Corresponding author. E-mail: i5ni@civil.auc.dk
}

than sinks. Marine ecosystems are presently estimated to play only a modest role in the global methane budget, their contribution representing between 1 and $10 \%$ of the total emissions (Cicerone \& Oremland 1988, Bange et al. 1994). Although shelf and estuaries represent only 15 and $0.4 \%$ of the global ocean area, they contribute about 68 and 7 to $10 \%$ of the total oceanic emissions respectively (Bange et al. 1994, Upstill-Goddard et al. 2000, Middelburg et al. 2001).

Methane concentrations in estuaries are generally orders of magnitude higher than the atmospheric equi- 
librium and decrease with increasing salinity (de Angelis \& Lilley 1987, Scranton \& McShane 1991, de Angelis \& Scranton 1993, Upstill-Goddard et al. 2000, Middelburg et al. 2001). This distribution is not only governed by conservative mixing of highly saturated freshwaters, since large sources and sinks have been identified in the estuarine zone (Sansone et al. 1999). They include production in sediments, in particular at estuarine turbidity maxima (Upstill-Goddard et al. 2000), input from tidal flats (Kelley et al. 1995, Middelburg et al. 2001), oxidation in surface sediment (van der Nat et al. 1997) and in the water column (de Angelis \& Scranton 1993), and emission to the atmosphere (Upstill-Goddard et al. 2000, Middelburg et al. 2001).

Intensive studies of methane dynamics in estuaries, including fluxes, production and/or oxidation rate measurements, are mostly restricted to tidal systems (e.g. de Angelis \& Scranton 1993, Kelley et al. 1995). Tidal estuaries are highly dynamic, with high current speeds, high turbidities, frequent sediment resuspensions, and the presence of large tidal flats. In these systems, high turbulence favours methane emission (Middelburg et al. 2001); methane oxidation is significant in the low salinity region (de Angelis \& Scranton 1993); methane production may occur in oxygen-depleted maximum turbidity zones (Upstill-Goddard et al. 2000); and tidal flats are a major methane source (Kelley et al. 1995, Middelburg et al. 2001). In contrast, non-tidal estuaries are less dynamic, have no tidal flats, and are still poorly documented in terms of methane dynamics. Bange et al. (1998) recently re-

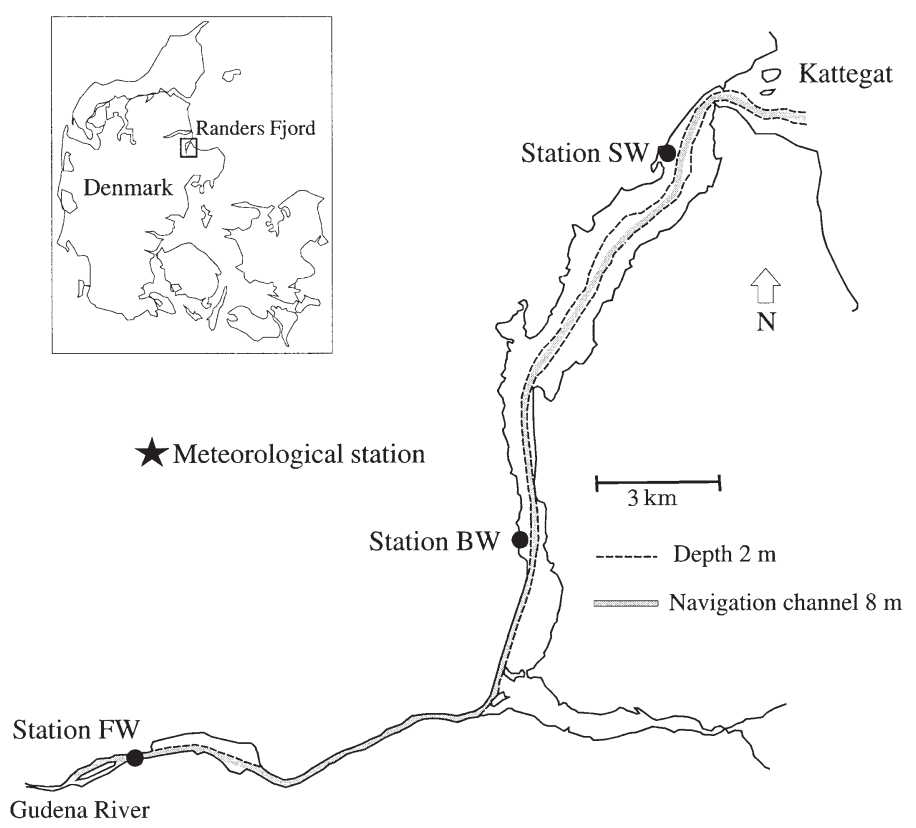

Fig. 1. Map of Randers Fjord showing the 3 sampling stations. FW: freshwater; BW: brackish water; SW: saltwater ported high methane concentrations in such a system in the Southern Baltic Sea. Here, we present measurements of methane concentrations, oxidation rates and fluxes at the sediment water interface in the Randers Fjord, a shallow non-tidal estuary on the eastern coast of Denmark.

\section{MATERIALS AND METHODS}

Study site and sampling. Randers Fjord (Fig. 1) is a $30 \mathrm{~km}$ long, non-tidal estuary, where freshwater flowing from the Gudenå River, mixes with saltwater from the Kattegat (salinity 27 to 30 ). The average freshwater discharge is $37 \mathrm{~m}^{3} \mathrm{~s}^{-1}$ (Sømod et al. 1999). The basin contains large areas of natural wetlands and flood plains which are important sources of methane (King 1990). The limit of salt intrusion is located around the city of Randers. The estuary is shallow (average $1.7 \mathrm{~m}$ ), except in the navigation channel, where dredging maintains a depth of $8 \mathrm{~m}$ (Fig. 1). Waters are well mixed in the shallow area and highly stratified in the navigation channel; here surface water salinities are similar to those in the adjacent shallow area, but bottom water salinities are up to 10 units higher. The surface area of the fjord is $19.4 \mathrm{~km}^{2}$, and the residence time of waters about $1 \mathrm{wk}$ (Nielsen et al. 1991).

Randers Fjord suffers from eutrophication problems. Both inputs of organic carbon from freshwater phytoplankton and in situ primary production are important during spring and summer (Nielsen et al. 1991, Sømod et al. 1999). This leads to high chlorophyll a concentrations all along the estuarine gradient, with values occasionally reaching $50 \mu \mathrm{g} \mathrm{l} \mathrm{l}^{-1}$ (Nielsen et al. 1991). The mineralisation of this organic matter in the water and surface sediment of the fjord leads to oxygen depletions, which are at a maximum in August and particularly important in the bottom waters and the confined waters of the channel, where oxygen concentrations can reach $20 \%$ of saturation. Waters in the shallow areas remain however relatively well oxygenated (minimum $=80 \%$ saturation in August: Sømod et al. 1999).

Between February and December 2000, we studied 3 stations in the estuary (Fig. 1). Water samples were collected throughout 2000 at a shallow saltwater station (SW) at the mouth of the fjord (salinity 17 to 23), at a shallow brackish water station (BW) inside the estuary (salinity 3 to 7) and at a freshwater station (FW) in the Gudenå River (depth $8 \mathrm{~m}$ ). Sampling frequency for water varied between 7 and $40 \mathrm{~d}$ and included an intensive weekly sampling in May. Methane oxidation in water was measured on 5 occa- 
sions: at all stations in May 2000, and at Stns BW and SW in November 2000. Sediment cores were collected at Stns BW and SW only, from fast-moving and wellaerated parts of the estuary accessible from the bank. Stn SW sediment is sandy/muddy with a water content of $25 \%$, a porosity of $0.45 \mathrm{~cm}^{3} \mathrm{~cm}^{-3}$, and an organic carbon content of $0.3 \%$. Stn BW sediment is muddy, with a higher water content $(60 \%$ in the first $1 \mathrm{~cm}$ and $40 \%$ below), a higher porosity $\left(0.80 \mathrm{~cm}^{3} \mathrm{~cm}^{-3}\right.$ in the first $1 \mathrm{~cm}$ and 0.60 below) and an average organic carbon content of $2 \%$. Cores were collected at Stns SW and BW in March, May, July, September, November and December 2000 for methane fluxes and from July to December for methane profiles.

Methane concentration in water. Water samples were collected in two $120 \mathrm{ml}$ pre-weighed serum bottles. The latter were completely filled with water and sealed with rubber stoppers and aluminium crimps. Analysis was initiated within $2 \mathrm{~h}$. In the laboratory, a headspace was created in the bottles by injecting $50 \mathrm{ml}$ of nitrogen, maintaining the bottles bottom-up and simultaneously expelling water by a second needle. The bottles were weighed, vigorously shaken, and left to equilibrate at ambient temperature for at least $2 \mathrm{~h}$. Triplicate $0.3 \mathrm{ml}$ gas samples were sampled from the headspace with a gas-tight syringe and injected into a Chrompack 438 gas chromatograph with a $(2 \mathrm{~m} \times$ $2 \mathrm{~mm}$ ) Haysep column and a flame ionisation detector. The methane concentration was quantified from injection of known standards, cross-calibrated with NOAA standards. In situ methane concentrations were calculated using the solubility coefficient of methane of Yamamoto et al. (1976) as a function of temperature and salinity.

Methane oxidation in water. Eight $120 \mathrm{ml}$ bottles were filled completely with water and incubated for 4 to $8 \mathrm{~d}$ at in situ temperature in the dark. Every 1 or $2 \mathrm{~d}$, a headspace was created as described above in 2 of the bottles to determine the methane concentration. Methane oxidation rates were calculated by linear regression of the temporal decrease in methane with time $\left(\mathrm{r}^{2}>0.90\right.$; detection limit at around $\left.0.2 \mathrm{nmol}^{-1} \mathrm{~d}^{-1}\right)$.

Methane exchange with the atmosphere. Methane emissions to the atmosphere were estimated using the wind speed parameterisation of the piston velocity from Cole \& Caraco (1998). This choice was motivated by the absence of tidal influence that results in low water currents $\left(<20 \mathrm{~cm} \mathrm{~s}^{-1}\right)$, the high wind speeds in Denmark, the relatively flat topography of the region, the broadness of the estuarine zone, and the absence of protection of the fjord by banks or trees. Schmidt numbers for methane $\left(\mathrm{SC}_{\mathrm{CH}_{4}, t_{s}}\right)$ were calculated from surface water temperatures and salinities using the polynomial equations derived by Wanninkhof (1992). The piston velocity of carbon dioxide at $20^{\circ} \mathrm{C}\left(K_{600}\right)$ was calculated from wind speeds at $10 \mathrm{~m}$ derived from monthly median values observed during the 1961 to 1998 period (Cappelen \& Jørgensen 1999) at a station located $10 \mathrm{~km}$ north-west of the fjord (Fig. 1), using the empirical relationship of Cole \& Caraco (1998). The piston velocity for methane, $K_{\mathrm{CH}_{4}, t, s_{1}}$ at in situ temperature and salinity was calculated from $K_{600}, S_{\mathrm{CH}_{4}, t, s}$ and a Schmidt number of $\mathrm{CO}_{2}$ at $20^{\circ} \mathrm{C}$ of 600 , using the relationship of Jahne et al. (1987) and a Schmidt number exponent of 0.67 (Frost \& Upstill-Goddard 1999). Finally, the flux to the atmosphere was calculated according to

$$
F=K_{\mathrm{CH}_{4} t, s}\left(C_{\mathrm{w}}-\alpha C_{\mathrm{a}}\right)
$$

where $C_{\mathrm{w}}$ is the methane concentration in water, $C_{\mathrm{a}}$ is the methane concentration in air (73 nM) and $\alpha$ is the solubility of methane in water (Yamamoto et al. 1976).

Methane profiles in sediments. Four sediment cores for methane profiles, porosity and water content (height $12 \mathrm{~cm}$, diameter $3.4 \mathrm{~cm}$ ) were sampled at Stns BW and SW. For methane profiles, 2 cores were sectioned at $1 \mathrm{~cm}$ intervals for the top $4 \mathrm{~cm}$ and at $2 \mathrm{~cm}$ intervals below. The sediment slices (approx. $13 \mathrm{~g}$ ) were rapidly transferred into pre-weighed $50 \mathrm{ml}$ glass vials containing $5 \mathrm{ml} \mathrm{NaOH}(0.5 \mathrm{~N})$. Vials were sealed with rubber stoppers, weighed, vigorously shaken to break up the sediment, and allowed to equilibrate for at least $3 \mathrm{~h}$ before analysis. The methane concentration in the equilibrated gas phase was determined as described above for the water samples. The values were corrected for the methane concentration in the laboratory air. The methane concentration in the pore water was determined using the water content at each depth intervals determined on the 2 other cores. These 2 cores were sectioned at the same intervals as above, and slices were mixed in pre-weighed aluminium cups, weighed wet, dried overnight at $85^{\circ} \mathrm{C}$, and weighed dry.

Methane sediment-water fluxes. Six sediment cores (sediment height approx. $15 \mathrm{~cm}$, diameter $8 \mathrm{~cm}$ ) were sampled at Stns BW and SW. The cores were sealed with a complete water column and with no contact between the overlying water and the atmosphere. Back in the laboratory, 3 cores were used for oxygen uptake (as part of another study) and 3 for methane fluxes.

Methane fluxes were measured with 2 different methods. First a headspace technique was used, whereby about one-half of the overlying water was gently siphoned off and cores were sealed with a headspace at around $300 \mathrm{ml}$. Equilibration between water and gas was optimised by placing the magnetic stirrers just below the water surface. Incubations were performed in the dark at in situ temperature in a thermostatic chamber. The water overlying the sediment was continu- 
ously stirred (200 rpm) to reproduce the in situ turbulent exchange at the sediment-water interface. The methane accumulation in the headspace was determined at $2 \mathrm{~h}$ intervals by sampling triplicate $0.3 \mathrm{ml}$ gas samples in the headspace. Methane fluxes were calculated by linear regression $\left(r^{2}>0.95\right)$ of the temporal increase in the total methane present in the cores.

In June 2000, the fluxes measured with the headspace technique were compared to those obtained with a non-headspace technique. The latter were performed in the 3 cores incubated in the dark, at in situ temperature, without a headspace, and stirred at $200 \mathrm{rpm}$ for the oxygen uptake. Initial and final methane concentrations were measured in water samples rapidly siphoned off at the beginning and at the end of incubations. On the following day, the cores were incubated a second time. The water was replaced with water kept for $1 \mathrm{~d}$ in a jerrycan at in situ temperature and in contact with air, resulting in an initial methane concentration in the incubation $\sim 70 \%$ lower than that in situ.

In September 2000, this no-headspace technique was further developed to allow the time-course of methane to be followed during the incubations. In each of the 3 cores, two $5 \mathrm{ml}$ syringes with needles were placed at the opposite sides of the rubber stoppers. The water overlying the sediment was sampled at $2 \mathrm{~h}$ intervals. One syringe was filled with water from the site kept in $12 \mathrm{ml}$ bottles without air at in situ temperature. This 'dilution water' $(5 \mathrm{ml})$ was homogenised with the water overlying the sediment ( 600 to $750 \mathrm{ml}$ ) by alter-
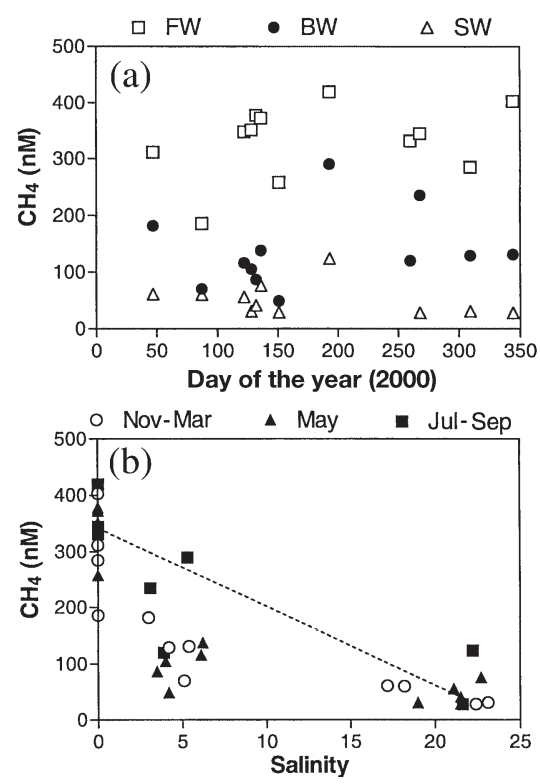

Fig. 2. (a) Time-course of methane concentrations at the freshwater (Stn FW), brackish water (Stn BW) and saltwater (Stn SW) stations along the Randers Fjord, during 2000; (b) distribution of methane concentrations as a function of salinity natively pulling the 2 syringes up and down 5 times. A $5 \mathrm{ml}$ water sample was then collected and transferred to a $12 \mathrm{ml}$, pre-weighed and sealed serum bottle. This bottle had been flushed with nitrogen and a vacuum of $5 \mathrm{ml}$ had been created immediately before sampling. The methane concentration was then measured as described previously. Correction for dilution was made using the in situ methane concentration in the dilution water, oxidation in the water being negligible compared to oxidation in the sediment cores.

The results of the headspace and no-headspace techniques were compared in July and September 2000. They were similar at Stn SW, but very different at Stn BW. Consequently, an additional experiment for Stn BW was conducted in September, wherein fluxes were measured under 3 different conditions: 3 cores were first incubated without headspace; a headspace was then created; and finally the headspace was flushed for $2 \mathrm{~h}$ with nitrogen to obtain anoxic conditions and inhibit aerobic methane oxidation.

Potential methane oxidation in surface sediments. The potential aerobic methane oxidation at the sediment surface was measured in July 2000 at Stns SW and BW. The upper $1 \mathrm{~cm}$ of 3 sediment cores (diameter $4.6 \mathrm{~cm}$ ) was sampled, homogenised and divided into fourteen $60 \mathrm{ml}$ serum bottles ( $5 \mathrm{~g}$ of sediment in each). The sediment was mixed with $5 \mathrm{~g}$ of filter-sterilized $(0.2 \mu \mathrm{m}$ pore size) water from the sampling site. Bottles were then sealed with rubber stoppers and aluminium crimps. Gases initially present in the sediment were removed from the slurries by evacuation with air (5 times). The methane in the headspace was adjusted in duplicate to 7 different concentrations between 10 and $20000 \mathrm{ppm}$ (corresponding to between 0.01 and $60 \mu \mathrm{M}$ dissolved in the slurry) by adding pure methane. The bottles were then incubated in the dark at room temperature, and methane in the headspace was measured approximately every $12 \mathrm{~h}$. Potential methane oxidation rates at the different concentrations were obtained from the slope of the methane decrease during 24 to $48 \mathrm{~h}$, which were linear with $\mathrm{r}^{2}>0.95$. The half-saturation constant $\left(K_{\mathrm{m}}\right)$ and the maximum potential rate $\left(V_{\max }\right)$ were calculated using a non-linear fit of the Michaelis-Menten equation. At Stn SW, a threshold concentration of $5 \mu \mathrm{M}$ was assumed in order to calculate the kinetic constants.

\section{RESULTS}

\section{Methane concentration in water}

River and estuarine waters were always supersaturated in dissolved methane in relation to the atmospheric equilibrium of 2 to $3 \mathrm{nM}$ (Fig. 2). Methane 
Table 1. Methane oxidation in water $\left(\mathrm{nmol}^{-1} \mathrm{~d}^{-1}\right)$. FW: freshwater; BW: brackish water; SW: saltwater; nd: not determined

\begin{tabular}{|lrc|}
\hline Stn & May 2000 & Nov 2000 \\
\hline FW & 15.2 & nd \\
BW & 2.3 & 3.1 \\
SW & $<0.2$ & $<0.2$ \\
\hline
\end{tabular}

concentrations range from 186-420, 70-290 and 28-124 nM, with median values of 347, 125 and $41 \mathrm{nM}$, at Stns FW, BW and SW respectively. This concentration range and decrease seawards have previously been reported for other estuaries (e.g. de Angelis \& Lilley 1987, de Angelis \& Scranton 1993, Bange et al. 1998, Upstill-Goddard et al. 2000, Middelburg et al. 2001). The relationship with salinity (Fig. 2b) was not linear, the decrease between Stns FW (salinity 0) and BW (salinity 3 to 7 ) being almost always much larger than the decrease between Stns BW and SW (salinity 17 to 23). The time-courses of methane concentration (Fig. 2a) showed rapid changes at short time-scales (e.g. between Days 139 and 150 and Days 260 and 268). With a median wind speed of $5.1 \mathrm{~m} \mathrm{~s}^{-1}$ (Cappelen \& Jørgensen 1999), the calculated median fluxes to the atmosphere were 355, 126 and $40 \mu \mathrm{mol} \mathrm{m} \mathrm{m}^{-2} \mathrm{~d}^{-1}$ at Stns FW, BW and SW respectively.

\section{Methane oxidation in water}

Methane oxidation rates in water, measured in May and October 2000, are shown in Table 1. At Stn BW, oxidation rates were similar in May and October and 5 to 7 times lower than at Stn FW in May. De Angelis \& Scranton (1993) reported similar and higher oxidation rates in the low-salinity region of the Hudson estuary. At Stn SW no oxidation could be detected with the method. Oxidation rates in coastal marine waters are often below the detection limit of the method we used here (Griffiths et al. 1982, Scranton \& McShane 1991).

\section{Methane profiles in sediments}

Methane profiles in the sediment showed very different patterns at Stns BW and SW (Fig. 3). At Stn BW, in June and September, the methane concentration was significantly lower in the first $1 \mathrm{~cm}$ of sediment than in the overlying water. In June, the methane concentration was even lower at $1.5 \mathrm{~cm}$ depth. Below this, the methane concentration increased progressively with depth, reaching 400 to $600 \mathrm{nM}$ at $9.5 \mathrm{~cm}$ depth. At Stn SW, methane concentrations were relatively con-

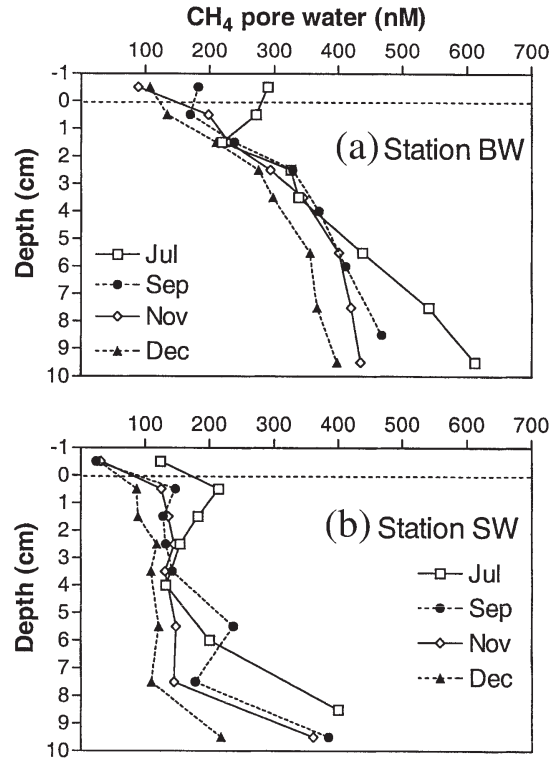

Fig. 3. Vertical profiles of methane concentrations in sediment pore water and overlying water from the brackish (Stn BW) and marine (Stn SW) stations

stant between 1 and $7 \mathrm{~cm}$ ( 100 to $150 \mathrm{nM})$. An exception occurred in June, when a net maximum was observed just below the sediment surface. Below $7 \mathrm{~cm}$, methane concentration increased rapidly.

\section{Potential methane oxidation in surface sediments}

The results for potential aerobic methane oxidation in surface sediments in June 2000 are shown in Fig. 4. At Stn BW, methane oxidation was observed at in situ methane concentrations (70 to $290 \mathrm{nM}$ ). In the slurries,

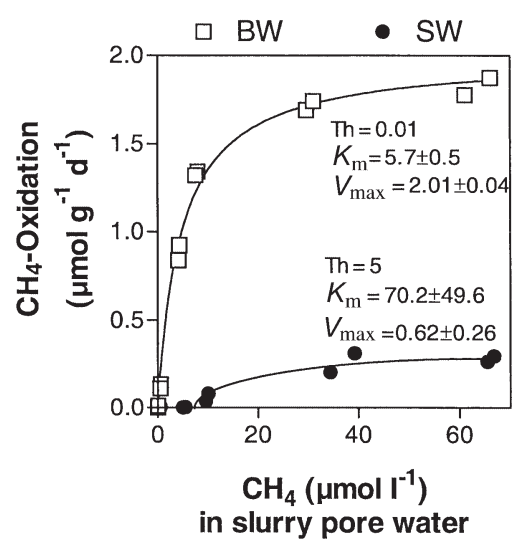

Fig. 4. Potential aerobic methane oxidation and MichaelisMenten parameters in surface sediments from the brackish (Stn BW) and saltwater (Stn SW) stations. Th: threshold $(\mu \mathrm{M})$; $K_{\mathrm{m}}$ : half-saturation constant $(\mu \mathrm{M}) ; V_{\max }$ : maximum oxidation rate $\left(\mu \mathrm{mol} \mathrm{g}{ }^{-1} \mathrm{~d}^{-1}\right)$ 


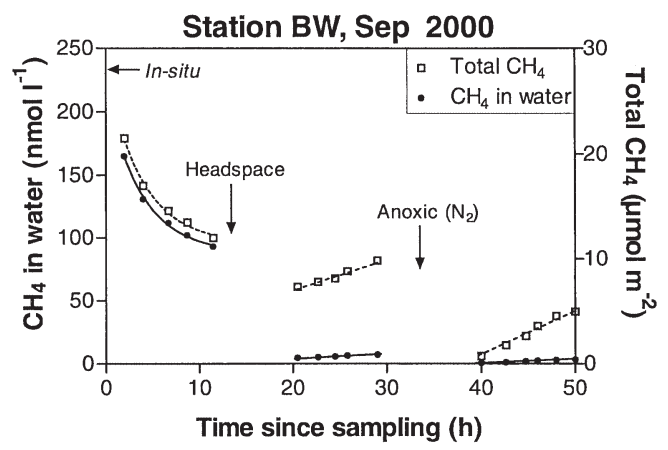

Fig. 5. Time-course of methane concentration in water and total methane in water and air normalised to the sediment surface during incubation of a sediment core from Stn BW, performed without a headspace (time: 2 to $12 \mathrm{~h}$ ), with a headspace under oxic conditions (time: 20 to $28 \mathrm{~h}$ ), and with a

headspace under anoxic conditions (time: 40 to $50 \mathrm{~h}$ )

no methane oxidation could be detected below $10 \mathrm{nM}$, suggesting that these methanotrophic bacteria are not able to consume atmospheric methane ( 2 to $3 \mathrm{nM}$ ). The methanotrophs present at Stn BW have a relatively low affinity for methane, the $K_{\mathrm{m}}$ value being in the range reported for natural freshwater wetlands (Segers 1998). However, in wetland sediments, $V_{\max }$ values can be 4 to 8 times higher (King 1990, Hanson \& Hanson
1996). At Stn SW, the threshold of $5 \mu M$ shows that no activity occurs at in situ concentrations. In addition, high $K_{\mathrm{m}}$ and low $V_{\max }$ reveal an extremely low affinity for methane and a low potential activity.

\section{Sediment-water fluxes}

The methane fluxes measured with the different techniques at Stns BW and SW are summarised in Table 2. From the comparison of the headspace and non-headspace techniques performed in July and September it can be seen that at Stn SW there was no significant difference in the methane flux measured with or without headspace and that the methane concentration in the water during the incubations had no significant effect on the flux. For this reason, the convenient headspace technique was chosen at Stn SW. In contrast, at Stn BW, the flux was directly upwards when using the headspace method and downwards (uptake of methane by the sediment) without a headspace. In addition, the methane uptake by the sediment was strongly affected by the methane concentration in the overlying waters.

The time-course for methane in the experiment in September 2000 with sediment cores from Stn BW is shown in Fig. 5. During the first period without a head-

Table 2. Methane fluxes at the sediment-water interface at Stns BW and SW obtained using the different techniques. Positive fluxes are directed upwards (release) and negative fluxes downwards (uptake). All results are from triplicate cores. Where noted, fluxes were recalculated at in situ concentrations using a first-order relationship (see 'Results' and Table 3). Incubation $\mathrm{CH}_{4}$ : average concentration in the water phase during the incubation

\begin{tabular}{|c|c|c|c|c|c|}
\hline $\begin{array}{l}\text { Date } \\
(2000)\end{array}$ & $\begin{array}{l}\text { Water } \\
T\left({ }^{\circ} \mathrm{C}\right)\end{array}$ & $\begin{array}{c}\text { In situ } \\
\mathrm{CH}_{4}(\mathrm{nM})\end{array}$ & $\begin{array}{c}\text { Incubation } \\
\mathrm{CH}_{4}(\mathrm{nM})\end{array}$ & $\begin{array}{l}\text { Methane flux } \\
\left(\mu \mathrm{mol} \mathrm{m} \mathrm{m}^{-2} \mathrm{~d}^{-1}\right)\end{array}$ & Method \\
\hline \multicolumn{6}{|l|}{ Stn BW } \\
\hline $28 \mathrm{Mar}$ & 4.8 & 70 & 4 & $+3 \pm 1$ & Headspace \\
\hline 16 May & 7.8 & 138 & 5 & $+8 \pm 2$ & Headspace \\
\hline \multirow[t]{4}{*}{$12 \mathrm{Jul}$} & 18.2 & 290 & 11 & $+15 \pm 3$ & Headspace \\
\hline & & & 198 & $-211 \pm 13$ & No-headspace, high conc. \\
\hline & & & 80 & $-35 \pm 8$ & No-headspace, low conc. \\
\hline & & & - & $-353 \pm 80$ & No-headspace, recalculated at in situ conc. \\
\hline \multirow[t]{3}{*}{$25 \mathrm{Sep}$} & 12.2 & 235 & - & $-110 \pm 9$ & No-headspace, recalculated at in situ conc. \\
\hline & & & 5 & $+10 \pm 3$ & Headspace \\
\hline & & & 2 & $+12 \pm 2$ & Headspace anoxic \\
\hline $05 \mathrm{Nov}$ & 10.2 & 129 & - & $-36 \pm 13$ & No-headspace, recalculated at in situ conc. \\
\hline $10 \mathrm{Dec}$ & 7.9 & 131 & - & $-19 \pm 9$ & No-headspace, recalculated at in situ conc. \\
\hline \multicolumn{6}{|l|}{ Stn SW } \\
\hline 12 Mar & 5.2 & 60 & 6 & $+3 \pm 1$ & Headspace \\
\hline 8 May & 8.1 & 31 & 4 & $+7 \pm 2$ & Headspace \\
\hline \multirow[t]{3}{*}{$19 \mathrm{Jul}$} & 17.8 & 124 & 6 & $+404 \pm 97$ & Headspace \\
\hline & & & 141 & $+393 \pm 72$ & No-headspace, high conc. \\
\hline & & & 37 & $+413 \pm 58$ & No-headspace, low conc. \\
\hline \multirow[t]{2}{*}{12 Sep } & 12.0 & 28 & 6 & $+77 \pm 21$ & Headspace \\
\hline & & & 33 & $+69 \pm 17$ & No-headspace \\
\hline $12 \mathrm{Nov}$ & 10.0 & 31 & 5 & $+13 \pm 4$ & Headspace \\
\hline $5 \mathrm{Dec}$ & 7.5 & 28 & 5 & $+20 \pm 6$ & Headspace \\
\hline
\end{tabular}


space ( 2 to $12 \mathrm{~h})$, the methane concentration decreased, following first-order kinetics. Also, the loss of methane in the sealed cores during the $2 \mathrm{~h}$ transport to the laboratory could be described by this first-order decrease. When creating the headspace, most of the remaining methane was transferred to the headspace and the concentration in the water phase was $\sim 5 \mathrm{nM}$. Under these conditions, a positive and linear efflux was measured. After flushing the headspace with nitrogen, the concentration in the water phase decreased again to less than $1 \mathrm{nM}$, and a positive and linear efflux was also observed. Effluxes measured with the headspace under oxic and anoxic conditions were not significantly different (Table 2).

The uptake of methane by the sediment at Stn BW can be described as follows:

$$
C(t)=C_{1} \mathrm{e}^{-K t}+C_{2}
$$

where $C_{1}$ is the span (nM), $C_{2}$ is the plateau (nM), and $K$ is the first-order rate constant $\left(\mathrm{h}^{-1}\right)$. The sum of $C_{1}$ and $C_{2}$ is equal to the methane concentration at the beginning of the incubation, and $C_{2}$ corresponds to the methane concentration at which uptake stops. Reproducibility between cores was very good, both for the first-order rate constant, $K$, and for the $C_{2}$ concentration (Table 3 ), $\mathrm{R}^{2}$ for individual regressions always being $>0.98$. The in situ methane uptake needs to be recalculated at the in situ methane concentration. The instantaneous flux during the incubations is given by

$$
F(t)=h \frac{\mathrm{d} C(t)}{\mathrm{d} t}=-h K C_{1} \mathrm{e}^{-K t}
$$

where $h$ is the height of water overlying the sediment. The time-dependent term can be eliminated from Eqs. (1) \& (2), which give

$$
F=-h K\left(C-C_{2}\right)
$$

where $C$ is the methane concentration in the water.

Fig. 6 shows the first-order relationships for methane uptake by the sediment at Stn BW. Values for $h, K$ and $C_{2}$ are given in Table 3 . From July to December, there was a net decrease in $h \cdot K$ and a slight increase in $C_{2}$. Fluxes in the in situ methane concentration (Table 2) were calculated from these equations.

Seasonal variations in methane fluxes at Stns BW (July to December 2000) and SW (March to December 2000) are shown in Fig. 7. There was a net peak in summer, both for methane uptake at Stn BW and for methane

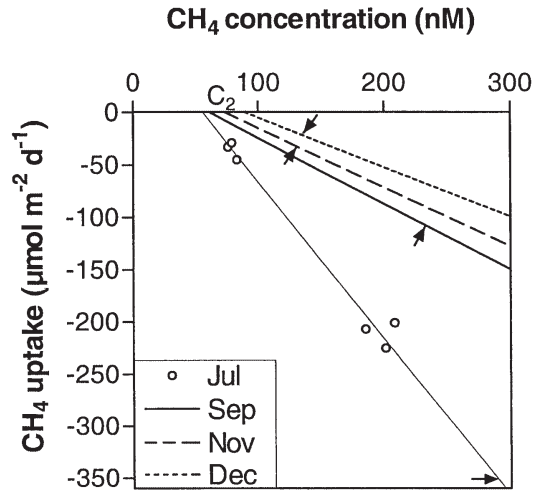

Fig. 6. First-order methane uptake by sediment at Stn BW From July to December 2000; actual values are given in Table 3. $C_{2}$ : compensation point; arrows indicate in situ conditions. In July, triplicate cores were incubated twice at different methane concentrations, and only initial and final concentrations were measured; from September to December, the time-courses of methane were followed and first-order relationships were calculated from Eq. (3)

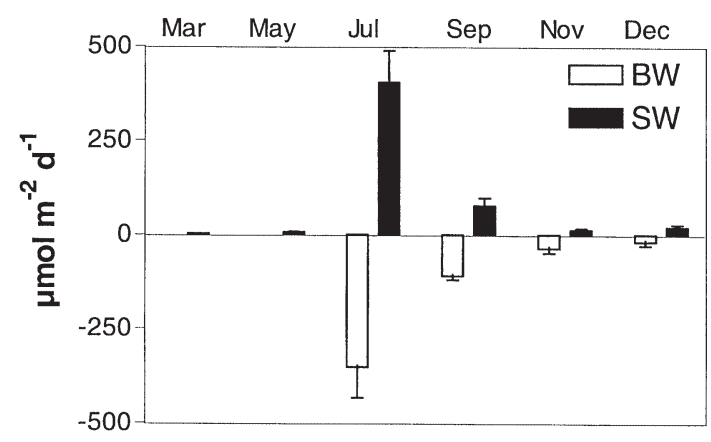

Fig. 7. Seasonal variations in methane fluxes across the sediment-water interface (negative $=$ uptake, positive $=$ release) at the brackish (Stn BW, July to December) and marine (Stn SW, March to December) stations

Table 3. First-order parameters of methane uptake by sediment at Stn BW. $h$ : water-column height in the core; $K$ : first-order decay observed during cores incubations; $h \cdot K$ and $C_{2}$ : slope and intercept of first-order uptake relationship (Eq. 3), respectively, where $C_{2}$ is the compensation point, i.e. the methane concentration at which uptake stops. For July 2000, values and standard deviations of $h \cdot K, C_{2}$ and methane flux are derived from the linear regression in Fig. 6. For September 2000 values and standard deviations of $K, h \bullet K, C_{2}$ and methane fluxes are calculated from individual cores

\begin{tabular}{|lcccccc|}
\hline $\begin{array}{l}\text { Date } \\
(2000)\end{array}$ & $\begin{array}{c}\text { In situ } \\
\mathrm{CH}_{4} \\
(\mathrm{nM})\end{array}$ & $\begin{array}{c}h \\
(\mathrm{~cm})\end{array}$ & $\begin{array}{c}K \\
\left(\mathrm{~h}^{-1}\right)\end{array}$ & $\begin{array}{c}h \cdot K \\
\left(\mathrm{~m} \mathrm{~d}^{-1}\right)\end{array}$ & $\begin{array}{c}\mathrm{C}_{2} \\
(\mathrm{nM})\end{array}$ & $\begin{array}{c}\text { Methane flux } \\
\left(\mu \mathrm{mol} \mathrm{m}^{-2} \mathrm{~d}^{-1}\right)\end{array}$ \\
\hline 12 Jul & 290 & $12.5 \pm 1.0$ & - & $1.5 \pm 0.2$ & $55 \pm 7$ & $-353 \pm 80$ \\
25 Sep & 235 & $13.3 \pm 1.2$ & $0.20 \pm 0.01$ & $0.6 \pm 0.1$ & $60 \pm 5$ & $-110 \pm 9$ \\
05 Nov & 129 & $12.7 \pm 1.3$ & $0.18 \pm 0.03$ & $0.6 \pm 0.2$ & $73 \pm 9$ & $-36 \pm 13$ \\
$10 \mathrm{Dec}$ & 131 & $12.9 \pm 0.9$ & $0.15 \pm 0.04$ & $0.5 \pm 0.2$ & $89 \pm 12$ & $-19 \pm 9$ \\
\hline
\end{tabular}


release at Stn SW. At Stn SW, the methane flux was higher in autumn than in spring, even at the same temperature.

\section{DISCUSSION}

\section{Methane oxidation, production and resulting exchange through the sediment-water interface}

Our results show completely different methane dynamics in the brackish and saltwater sediments of Randers Fjord, caused by differences in both oxidation and production rates. At Stn BW, methane oxidation exceeds methane production in the sediment, resulting in a downwards methane flux through the sedimentwater interface. At Stn SW, methane production exceeds methane oxidation in the sediment, resulting in an upwards methane flux. Globally, methane uptake at Stn BW and release at Stn SW are on the same order of magnitude (Fig. 7).

Aerobic methane oxidation activity decreased downstream in the fjord both in the water and at the sediment surface. Simultaneously, methane concentrations decreased and salinity increased. Both methane concentration and salinity seem to have a significant influence on the spatial distribution of methane oxidation activity in estuaries. In waters from the Hudson estuary, de Angelis \& Scranton (1993) reported high oxidation rates ( 4 to $167 \mathrm{nmol} \mathrm{l}^{-1} \mathrm{~d}^{-1}$ ) only at salinities below 6 , rates at higher salinities being 1 to 2 orders of magnitude lower. Adding salt and filtered seawater to their freshwater samples resulted in a strong inhibition of methane oxidation. In coastal saltwaters with methane concentrations between 3 and $43 \mathrm{nM}$, reported in situ methane oxidation rates were between 0.00024 and $0.15 \mathrm{nmol} \mathrm{l}^{-1} \mathrm{~d}^{-1}$ (Griffiths et al. 1982, Scranton \& McShane 1991). Potential rates measured at methane concentrations of several $\mu \mathrm{M}$ remained below $1 \mathrm{nmol}$ $\mathrm{l}^{-1} \mathrm{~d}^{-1}$ (Scranton \& McShane 1991). Higher oxidation rates have, however, also been reported in some coastal waters, but only at in situ methane concentrations in the micromolar range (Sansone \& Martens 1978, Fenchel et al. 1995).

At the sediment surface, aerobic methane oxidation is well documented for freshwater environments but poorly documented for marine systems. In coastal Danish sediments, Iversen (1996) reported rates between 0 and $1100 \mu \mathrm{mol} \mathrm{m}^{-2} \mathrm{~d}^{-1}$, corresponding to 0 to $99 \%$ of the flux measured in anoxic conditions, and with large seasonal variations. This is very similar to what has been reported for lakes (Frenzel et al. 1990), wetlands (King 1990) and freshwater tidal marshes (Kelley et al. 1995). It suggests that methanotrophs can better compensate the effect of salinity at the sediment surface than in overlying waters. However, in hypersaline microbial mats (salinity > 90), Conrad et al. (1995) could not detect any oxidation at the sediment surface, although high concentrations of oxygen and methane were available. Our results show that at Stn SW in Randers Fjord, methanotrophic bacteria are present in the sediments but are not active at ambient methane concentrations (Fig. 4).

In contrast, methanotrophic bacteria are very active at Stn BW, where uptake of methane at the sedimentwater interface was observed. To our knowledge, this is the first time such uptake has been reported. This brackish region of Randers Fjord is probably not an exception; uptake of methane by the sediment may occur in other systems where advection of methanerich waters is important. Also, it might partly explain the lower bottom methane concentrations observed occasionally in other rivers and estuaries (de Angelis \& Lilley 1987, de Angelis \& Scranton 1993, Bange et al. 1998).

To allow such uptake of methane from the water column, aerobic methane oxidation at the sediment surface has first to consume all the methane produced deeper in the sediment. By applying Fick's law, using the methane gradients observed between 1.5 and $9.5 \mathrm{~cm}$ (Fig. 3a) and the diffusion coefficient for methane (Iversen \& Jørgensen 1993), we calculated the flux of methane diffusing from deeper sediment at Stn BW. This varied between 4 and $11 \mu \mathrm{mol} \mathrm{m}^{-2} \mathrm{~d}^{-1}$ in December and July respectively. These values are very close to the upwards methane effluxes obtained with the headspace technique, as well as that obtained in anoxic conditions in September 2000 (Table 2). When using the headspace technique, methane oxidation was almost completely inhibited, since the methane concentration in the water phase (Table 2) became lower than the threshold of the methanotrophs present at the sediment surface (Fig. 4). Similar to gas exchange between plant leaves and the atmosphere (Schjoering et al. 1998), methane exchange between the sediment and the water column at Stn BW appears to function according to the compensation point principle. Depending on the difference between the methane concentration in the water and the $\mathrm{CH}_{4}$ compensation-point (the $C_{2}$ term in Eq. 3), methane fluxes may change in magnitude and direction.

The total methane oxidation at the sediment surface, calculated as the sum of the sediment uptake and the methane diffusion from below $1.5 \mathrm{~cm}$, varied between 23 and $364 \mu \mathrm{mol} \mathrm{m}{ }^{-2} \mathrm{~d}^{-1}$ in December and July respectively. These values are comparable to potential oxidation rates obtained in sediment slurries. Oxygen penetration in the sediment at Stn BW was 1.6 and $2 \mathrm{~mm}$ in September and December 2000 respectively (authors' unpubl. data). Using a first-order approximation for 
methane concentrations between the threshold and the half-saturation constant (Fig. 4) and applying this rate to the methane concentration in the water column and one-half of the oxygen penetration zone (average $0.8 \mathrm{~mm}$ ) gives potential methane oxidation rates of 50 and $120 \mu \mathrm{mol} \mathrm{m}^{-2} \mathrm{~d}^{-1}$ in December and July respectively. In December, the higher potential rates than in situ rates can be explained by the fact that sediment slurries were incubated at room temperature $\left(22^{\circ} \mathrm{C}\right)$. In July, however, the difference in temperature was less important and in situ rates were higher than potential rates. This was probably due to irrigation and bioturbation, which transport oxygen deeper in the sediment. Bioturbation also explains the methane minimum observed at $1.5 \mathrm{~cm}$ depth in June 2000 (Fig. 3). Several worm tubes were visible in the 4 to 5 upper $\mathrm{cm}$ of these sediments, and after the cores had been allowed to turn anoxic, dead Nereis sp. (3 to 4 per core, $\sim 7 \mathrm{~cm}$ long) were observed in the cores.

Since little change in oxygen penetration was observed seasonally in these sediments, the seasonal variation in methane uptake by the sediment at Stn BW (Fig. 7) must have been due to the seasonal dynamics of the population of methanotrophs at the sediment surface and to the variations in methane concentration in the overlying water. The slopes of the first-order relationships for methane uptake $(h \cdot K$ in Table 3) decreased by a factor of 3 between July and September 2000 and stabilized later in autumn and winter. This is relatively consistent with results in coastal sediments of Iversen (1996), who observed a non-linear response of aerobic methane oxidation to temperature, with a maximum stimulation at temperatures around $20^{\circ} \mathrm{C}$. However, there was also a change in the compensation point, $C_{2}$, from summer to winter (Table 3), showing an increase in the threshold of methane oxidation in winter.

In addition to large differences in methane oxidation, there were also large differences in methane production in the sediments from Stns BW and SW. In July, methane production in the sediment at Stn SW (efflux measured in core incubations; Table 2) was $~ 40$ times higher than at Stn BW (efflux from $<2 \mathrm{~cm}$ calculated using the methane profiles from Fig. 3a). In contrast, benthic oxygen uptake was very similar at these 2 stations and followed the same seasonal cycle with a minimum $\left(-10 \mathrm{mmol} \mathrm{m}^{-2} \mathrm{~d}^{-1}\right)$ in March 2000 and a maximum $\left(-400 \mathrm{mmol} \mathrm{m} \mathrm{m}^{-2} \mathrm{~d}^{-1}\right.$ ) in July 2000 (author's unpubl. data). The methane profiles in the sandy/muddy sediment at Stn SW (Fig. 3) show no evident gradient between 0 and $7 \mathrm{~cm}$. This is presumably due to the presence of cockles and gasper (Cardium edule and Mya arenaria) located at a depth of $\sim 8$ to $10 \mathrm{~cm}$ (Sømod et al. 1999), where a shell-rich horizon is present and methane is regularly vented out by bio- turbation. In contrast, a net methane maximum was observed just below the surface in June 2000 (Fig. 3), when microphytobenthos mats (diatoms) were visible at the sediment surface. It appears that most of this methane was produced in the presence of sulfate, which suggests a supply of specific substrates. Noncompetitive substrates for methanogens in marine sediments include methylamines (Oremland \& Polcin 1982) and dimethyl sulfide (van der Maarel \& Hansen 1997). In coastal sediments, these compounds are present in algae, benthic animals and bacteria and are also produced during decomposition of organic material (Oremland \& Polcin 1982, Wang \& Lee 1994) In Randers Fjord at Stn SW, microphytobenthos could be the major source of non-competitive substrates for methanogens at the sediment surface.

\section{Methane transfer through the estuary and emissions to the atmosphere}

Methane carried by freshwater is dispersed over the broad and shallow area of the fjord, where it is partly oxidised in the sediment and partly released to the atmosphere. Downstream, at higher salinity, new production of methane occurs and oxidation is inhibited. The relative extent of these 2 regions with inverse methane fluxes through the sediment-water interface will not be assessed in this study, since our data are restricted to 2 stations. The broadness and shallowness of the estuarine zone allows the sediment to play a major role in methane dynamics compared to watercolumn processes in the deeper river. This estuarine morphology also favours emissions by increasing the surface exchange with the atmosphere. Rapid changes in methane concentrations (Fig. 2a) suggest that short and episodic events (stormy winds that decrease the methane concentration or high river discharges that increase it), rather than seasonal variations in methane production and consumption, prevail in determining methane concentrations in Randers Fjord.

Fig. 8 compares the methane uptake by the sediment with the emission to the atmosphere at Stn BW. The ratio between these 2 fluxes is plotted as a function of the wind speed and the methane concentration in the water, which are both highly variable on short timescales. It can be seen that methane oxidation at the sediment surface may be more than twice the atmospheric flux in summer. In contrast, during winter the atmospheric flux is 5 to 9 times higher than the sediment uptake. It is interesting to note that high concentrations of methane in the water column favour sediment uptake versus emission, resulting in a multiplicative control by wind: during low wind, the atmospheric flux is decreased and riverine methane 


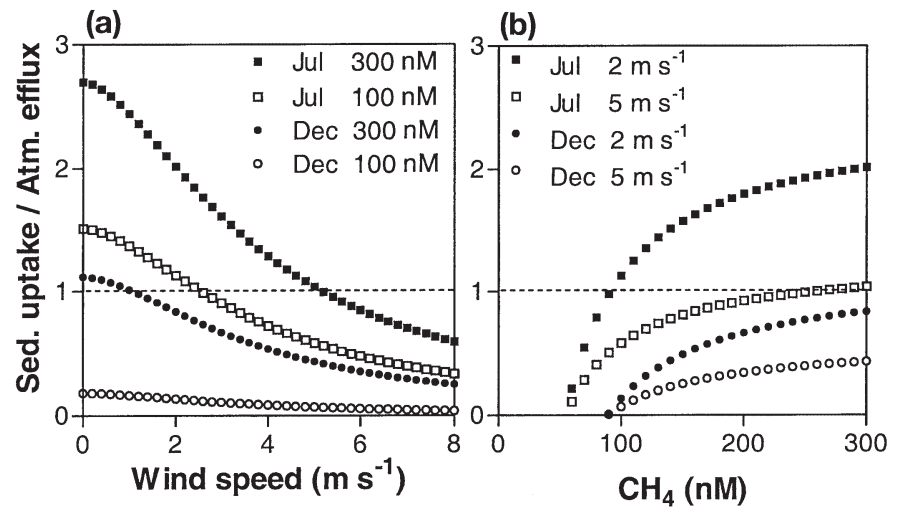

Fig. 8. Ratios between methane uptake by the sediment and methane efflux to the atmosphere at Stn BW, as a function of (a) wind speed at $10 \mathrm{~m}$ for 2 methane concentrations in the water in summer and winter, and (b) methane concentration in the water for 2 wind speeds in summer and winter

builds-up in the brackish waters, enhancing sediment uptake; during stormy weather, the rapid transfer of methane to the atmosphere decreases the methane concentration in the water closer to the compensation point, inhibiting sediment uptake.

The magnitude of the different methane sources and sinks at the 3 stations was calculated for summer and winter (Table 4). Oxidation rates in the water column are only rough estimates, since they were extrapolated from very few measurements using a $Q_{10}$ of 3 as typical for methanotrophs in freshwater environments (Segers 1998). However, these values allow a good understanding of methane transfers through the Randers Fjord. In the river (Stn FW), methane oxidation in the water is similar to the emission to the atmosphere in summer, but 1 order of magnitude lower during winter. Mostly because of the $8 \mathrm{~m}$ depth at this station, the turnover time of methane in the water is relatively long, about $5 \mathrm{~d}$. Even assuming an oxidation rate at the sediment surface similar to Stn BW, the turnover time remains of about $4 \mathrm{~d}$. This is longer than the time needed for freshwater to reach Stn BW, which confirms the freshwater origin of most of the methane in the brackish water. At Stn BW, owing to the shallow depth and the lower oxidation rates, the relative importance of water column oxidation decreases. In contrast, oxidation at the sediment surface provides a large methane sink, similar to the emission in summer, but 5 times lower in winter. Also because of the shallow depths, the turnover time at Stn BW is about $1 \mathrm{~d}$, which is much shorter than the resi- dence time of waters in the fjord. Consequently, the freshwater methane does not reach the mouth of the fjord, where most of the methane originates from the estuarine sediment. Turnover time of methane at the mouth of the fjord (Stn SW) is longer (about 1 to $5 \mathrm{~d}$ ) than that upstream, mostly because of lower concentrations in the water that decrease the emission to the atmosphere. At Stn SW in summer, the methane production exceeds the emission to the atmosphere by a factor 4 , showing that a large part of the methane produced in the fjord sediments is exported to the adjacent coastal waters of the Kattegat.

The role of the estuarine zone in the methane transfer between the river, the ocean and the atmosphere can also be calculated by comparing the input of methane by the river with the estuarine emission to the atmosphere. Average river flow and methane concentration give a freshwater methane input of $6.4 \mathrm{t} \mathrm{yr}^{-1}$. Applying the average of the methane emissions at Stns BW and SW to the overall surface of the fjord gives a

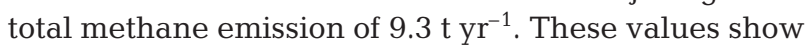
that river input accounts for more than two-thirds of the estuarine emission, which confirms that the estuary itself is an environment in which net methane production is rather limited (Middelburg et al. 2001).

In conclusion, several patterns of methane dynamics reported previously in tidal and turbid estuaries (de Angelis \& Scranton 1993, Upstill-Goddard et al. 2000, Middelburg et al. 2001) are also observed in shallow non-tidal systems: major input of methane by rivers, a large flux to the atmosphere, quantitatively important oxidation at low salinities, and a turnover time of methane in the water column that is shorter than the residence times of waters in the estuary. However, there are 2 major differences between these 2 kinds of systems: (1) Up-estuary methane oxidation mostly occurred at the sediment surface in this shallow system, resulting in uptake by the sediment. (2) In the

Table 4. Estimations of the different components of methane sources (positive) and sinks (negative) and residence time of methane in water column at the 3 stations studied. Emissions calculated using median wind speeds of 4.6 and $5.6 \mathrm{~m}$ $\mathrm{s}^{-1}$ for July and December respectively (Cappelen \& Jørgensen 1999). Oxidation in water estimated from values observed in May and September 2000 and a $Q_{10}$ of 3 (Segers 1998). nd: not determined

\begin{tabular}{|lcccccc}
\hline \multirow{2}{*}{$\begin{array}{l}\text { Sources/sinks } \\
\left(\mu \mathrm{mol} \mathrm{m} \mathrm{m}^{-2} \mathrm{~d}^{-1}\right)\end{array}$} & \multicolumn{2}{c}{ FW } & \multicolumn{2}{c}{ BW } & \multicolumn{2}{c}{ SW } \\
& Jul & Dec & Jul & Dec & Jul & Dec \\
\hline Emissions & -420 & -403 & -288 & -117 & -122 & -23 \\
Oxidation in water & -314 & -114 & -14 & -4 & $<0.1$ & $<0.1$ \\
Oxidation in surface sediment & nd & nd & -364 & -23 & $<0.1$ & $<0.1$ \\
Production in sediment & nd & nd & +11 & +4 & +404 & +12 \\
Turnover time in water $(d)$ & $4.6^{\mathrm{a}}$ & $6.2^{\mathrm{a}}$ & $0.5^{\mathrm{b}}$ & $1.8^{\mathrm{b}}$ & $0.6-2.6^{\mathrm{c}}$ & $2.3-4.7^{\mathrm{c}}$ \\
\hline
\end{tabular}

Turnover relative to ${ }^{a}$ emission and water column oxidation only, ball sinks, and ${ }^{\mathrm{c}}$ sources or sinks 
absence of tidal flats and creeks, there were no lateral inputs of methane as in tidal estuaries (Kelley et al. 1995, Middelburg et al. 2001); instead, shallow sediments colonised by microphytobenthos in the marine region were a significant source of methane.

Acknowledgements. We thank Kirsten Maagaard for technical assistance. G.A. was funded by an EU 'Marie Curie' postdoctoral grant. He thanks Henri Etcheber (Université Bordeaux 1, France) and Michel Frankignoulle (Université de Liège, Belgium) for continuous guidance and moral support.

\section{LITERATURE CITED}

Bange HW, Bartell UH, Rapsomanikis S, Andrea MO (1994) Methane in the Baltic and North Seas and a reassessment of the marine emissions of methane. Global Biogeochem Cycles 8:465-480

Bange HW, Dahlke S, Ramesh R, Meyer-Reil LA, Rapsomanikis S, Andrea MO (1998) Seasonal study of methane and nitrous oxide in the coastal waters of the southern Baltic Sea. Estuar Coast Shelf Sci 47:807-817

Cappelen J, Jørgensen B (1999) Observed wind directions and speed in Denmark with climatological standard normals, 1961-1998. Technical report 99-13, Danish Meteorological Institute, Copenhagen

Cicerone RJ, Oremland RS (1988) Biogeochemical aspects of atmospheric methane. Glob Biogeochem Cycles 2: 299-327

Cole JJ, Caraco NF (1998) Atmospheric exchange of carbon dioxide in a low-wind oligotrophic lake measured by the addition of $\mathrm{SF}_{6}$. Limnol Oceanogr 43:647-656

Conrad R, Frenzel P, Cohen Y (1995) Methane emission from hypersaline microbial mats: lack of aerobic methane oxidation. FEMS Microbiol Ecol 16:297-306

de Angelis MA, Lilley MD (1987) Methane in surface waters of Oregon estuaries and rivers. Limnol Oceanogr 32: 716-722

de Angelis MA, Scranton MI (1993) Fate of methane in the Hudson river and estuary. Glob Biogeochem Cycles 7: 509-523

Fenchel T, Bernard C, Esteban G, Finlay B, Hansen PJ, Iversen N (1995) Microbial diversity and activity in a Danish fjord with anoxic deep waters. Ophelia 43:45-100

Frenzel P, Thebrath B, Conrad R (1990) Oxidation of methane in the oxic surface layer of a deep lake sediment (Lake Constance). FEMS Microbiol Ecol 73:149-158

Frost T, Upstill-Goddard RC (1999) Air-sea exchange into the millennium: progress and uncertainities. Oceanogr Mar Biol Annu Rev 37:1-45

Griffiths RP, Caldwell BA, Cline JD, Broich WA, Morita RY (1982) Field observation of methane concentrations and oxidation rates in the southeastern Bering Sea. Appl Environ Microbiol 44:435-446

Hanson MR, Hanson RS (1996) Methanotrophic bacteria. Microbiol Rev 60:439-471

Iversen N (1996) Methane oxidation in coastal marine environments. In: Murrell CJ, Kelly DP (eds) Microbiology of atmospheric trace gases. Springer-Verlag, Berlin, p 51-68

Editorial responsibility: Otto Kinne (Editor),

Oldendorf/Luhe, Germany
Iversen N, Jørgensen BB (1993) Diffusion coefficients of sulfate and methane in marine sediments: influence of porosity. Geochim Cosmochim Acta 57:571-578

Jahne B, Münnich KO, Bosinger R, Dutzi A, Huber W, Libmer $P$ (1987) On the parameters influencing air-water gas exchange. J Geophys Res 92:1937-1949

Kelley CA, Martens CS, Ussler W III (1995) Methane dynamics across a tidally flooded riverbank margin. Limnol Oceanogr 40:1112-1129

King GM (1990) Dynamics and controls of methane oxidation in a Danish wetland sediment. FEMS Microbiol Ecol 74 309-324

Middelburg JJ, Nieuwenhuize J, Iversen N, Høegh N, de Wilde H, Helder W, Seifert R, Christof O (2001) Methane distribution in tidal estuaries. Biogeochemistry (in press)

Nielsen KB, Sømod B, Hansen D, Jensen C (1991) The aquatic environment of Randers Fjord 1990. County of Aarhus, Aarhus

Oremland RS, Polcin S (1982) Methanogenesis and sulfate reduction: competitive and non-competitive substrates in estuarine sediments. Appl Environ Microbiol 44: $1270-1276$

Sansone FJ, Martens CS (1978) Methane oxidation in Cape Lookout Bight, North Carolina. Limnol Oceanogr 23: 349-355

Sansone FJ, Holmes ME, Popp BN (1999) Methane stable isotopic ratios and concentrations as indicators of methane dynamics in estuaries. Glob Biogeochem Cycles 13: 463-474

Schjoerring JK, Husted S, Mattsson M (1998) Physiological parameters controlling plant-atmosphere ammonia exchange. Atmos Environ 32:491-498

Scranton MI, McShane K (1991) Methane fluxes in the southern North Sea: the role of European rivers. Cont Shelf Res 11:37-52

Segers R (1998) Methane production and methane consumption: a review of processes underlying wetland methane fluxes. Biogeochemistry 41:23-51

Sømod B, Larsen K, Hansen D, Düwel P, Andersen J (1999) The aquatic environment of Randers Fjord 1997. County of Aarhus, Aarhus

Upstill-Goddard RC, Barnes J, Frost T, Punshon S, Owens NJP (2000) Methane in the southern North Sea: low-salinity inputs, estuarine removal and atmospheric flux. Global Biogeochem Cycles 14:1205-1217

van der Maarel MJEC, Hansen TA (1997) Dimethylsulfoniopropionate in anoxic intertidal sediment: a precursor of methanogenesis via dimethyl sulfide, methanethiol, and methiolpropionate. Mar Geol 137:5-12

van der Nat FJWA, de Brouwer JCF, Middelburg JJ, Laanbroek HJ (1997) Spatial distribution and inhibition by ammonium of methane oxidation in intertidal freshwater marshes. Appl Environ Microbiol 63:4734-4740

Wang XU, Lee C (1994) Sources and distribution of aliphatic amines in salt marsh sediments. Org Geochem 22: 1005-1021

Wanninkhof R (1992) Relationship between gas exchange and wind speed over the ocean. J Geophys Res 97: 7373-7382

Yamamoto S, Alcauskas JB, Crozier TE (1976). Solubility of methane in distilled water and seawater. J Chem Eng Data 21:78-80

Submitted: February 19, 2001; Accepted: September 9, 2001 Proofs received from author(s): March 14, 2002 